\title{
The Influence OF JAVANESE ARChiteCtURAL FACADE AND ATMOSPHERE as a Potential in The Change of MICE Tourists into Leisure Tourists
}

\author{
Pengaruh Tampilan dan Atmosfer Arsitektural Budaya Jawa \\ Sebagai Potensi dalam Perubahan Wisatawan MICE Menjadi \\ WiSATAWAN LEISURE
}

\author{
Luh Ayu Perwita A.K ${ }^{1 *}$, Ofita Purwani ${ }^{2}$, Agung Kumoro Wahyuwibowo ${ }^{3}$ \\ Program Studi Arsitektur, Fakultas Teknik, Universitas Sebelas Maret ${ }^{1}$ \\ luhayuperwita@gmail.com* \\ Program Studi Arsitektur, Fakultas Teknik, Universitas Sebelas Maret ${ }^{2}$ \\ Program Studi Arsitektur, Fakultas Teknik, Universitas Sebelas Maret ${ }^{3}$
}

\begin{abstract}
Meetings, Incentives, Conferences and Exhibitions (MICE) is a type of tourism in large groups, planned well in advance, and brought together for a particular purpose. Surakarta as one of MICE destinations in Indonesia has hosted many national and international MICE events. The tourists who do MICE activity in Surakarta are expected to become leisure tourists who will visit Surakarta city anotther time. In order to make MICE tourists become leisure tourists later on, the Convention and Exhibition building which is the place of MICE tourist activity needs to show the elements of Javanese Culture as a means to fulfil their curiosity on the city and to make them want to know more. Showing Javanese Culture can be done not only through the facade of building but also by creating Javanese atmosphere inside the the building. The method is to use questionnare to find out what Javanese objects will be displayed on the facade of building and use Peter Zumthor's atmosphere design to bring up the cultural atmosphere in the building.
\end{abstract}

Keywords: MICE, Convention and Exhibition Building, Javanese Culture, Atmosphere Design

\section{PENDAHULUAN}

Penyelenggaraan Pertemuan, Perjalanan Insentif, Konvensi dan Pameran (Meeting, Incentive, Convention, and Exhibition) yang selanjutnya disebut MICE merupakan salah satu industri pariwisata yang memberikan dampak peningkatan pendapatan, memperluas lapangan pekerjaan serta mendorong masuknya investasi. Di era globalisasi sekarang ini, persaingan bisnis MICE telah bergeser dari persaingan antar perusahaan menjadi persaingan antar destinasi dan Kota Surakarta merupakan salah satu dari 16 daerah destinasi MICE di Indonesia yang ditetapkan oleh Kementerian Pariwisata Republik Indonesia.
Kepala Dinas Kebudayaan dan Pariwisata kota Solo, Widdi Srihanto mengatakan, "Selain memiliki daya tarik sebagai Kota Budaya dan pariwisata, Solo dinilai aman dan nyaman sehingga kerap dijadikan tempat penyelenggaraan MICE, ditambah lagi pada 2009, Kementrian Pariwisata dan Ekonomi Kreatif mencanangkan Kota Surakarta sebagai salah satu kota tujuan MICE.” (Bioza, 2017).

Menteri Pariwisata, Arief Yahya menyatakan bahwa wisatawan MICE berpotensi untuk menjadi wisatawan leisure. Pada umumnya peserta atau wisatawan MICE merupakan opinion leader yang berasal dari kalangan pengusaha, profesional, maupun pemerintahan. Tujuan destinasi MICE yang telah ditentukan 
oleh penyelenggara kegiatan tentunya diharapkan tidak hanya dapat menjadi lokasi kegiatan MICE tetapi juga dapat merepresentasikan potensi-potensi yang dimiliki destinasi tersebut sehingga nantinya wisatawan MICE tertarik untuk kembali berkunjung ke destinasi MICE tersebut sebagai wisatawan leisure guna menikmati potensi yang ada juga meningkatkan sektor pariwisata di destinasi MICE tersebut.

Memunculkan potensi yang dimiliki Kota Surakarta secara arsitektural antara lain memunculkan unsur-unsur Budaya Jawa pada bangunan Gedung Konvensi dan Ekshibisi yang merupakan wadah yang digunakan Wisatawan MICE beraktivitas. Tidak cukup hanya secara visual untuk memunculkan budaya Jawa pada bangunan tetapi atmosfer budaya Jawa juga harus dapat dimunculkan sehingga bangunan ini nantinya dapat merepresentasikan Kota Solo lebih dalam lagi. Seperti pemahaman Peter Zumthor dalam berarsitektur: "Arsitektur tidak terbatas pada sesuatu yang kasat mata, tetapi juga pada 'sense \& presence' -bagaimana kehadiran dari suatu bangunan arsitektural mempengaruhi siapa saja yang melihat, menikmati, atau terlibat dengannya- sederhana dalam bentuk namun memiliki 'substansi' yang kuat" (Zumthor, 2006). Ruang merupakan hal yang mendasar dalam arsitektur lebih dari topos dan spatium, seperti desain panggung yang membuat ruang tidak hanya dibuat menggunakan benda dan dinding, tetapi juga dengan cahaya, suara, warna, udara dan sejumlah cara konvensional lainnya seperti: simbol, gambar, teks dan lainnya. Semua faktor tersebut relevan karena apa yang berasal dari mereka mengaktifkan dan berkontribusi pada atmosfir yang diliputinya. (Bőhme, 2005).

\section{METODE}

Metode yang digunakan dalam menciptakan tampilan serta atmosfer Budaya Jawa dalam Gedung Konvensi dan Ekshibisi di Surakarta adalah sebagai berikut,

\subsection{Metode Pengumpulan Data}

a. Wawancara

Dilakukan sebagai proses penelitian dan pengumpulan data dari pihak-pihak terkait dengan karya arsitektur yang terbangun.

b. Survey Lapangan

Dilakukan untuk mengetahui dan merasakan secara langsung suasana yang ada di dalam bangunan yang merupakan representasi budaya Jawa di mata wisatawan

c. Survey melalui Internet \& Kuisioner Selain survey lapangan, survey melalui internet dan melalui kuisioner juga dilakukan guna mendapatkan dan mengetahui aspek authenticity wisata budaya di Surakarta seperti apa yang ada di bayangan wisatawan sehingga dapat diterapkan pada visual bangunan Gedung Konvensi dan Ekshibisi di Surakarta.

d. Studi Pustaka

Dilakukan untuk mendapatkan pemahaman literatur yang didapat dari buku, jurnal, maupun artikel.

\subsection{Metode Perencanaan Dan Perancangan}

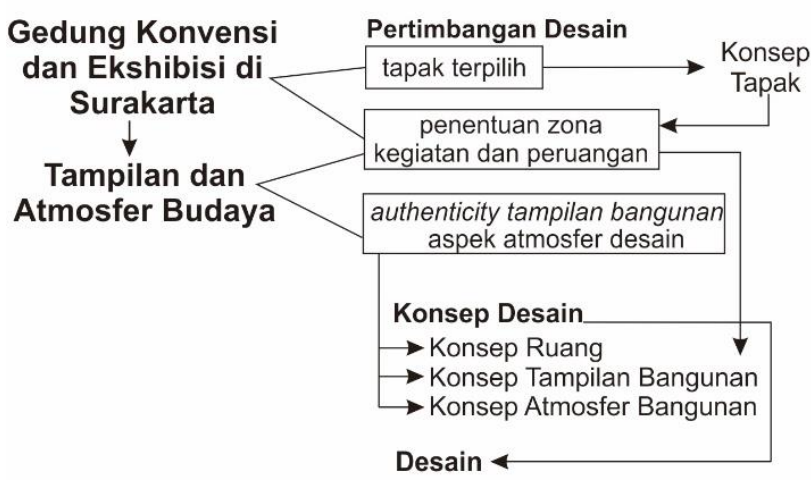

Bagan 1. Metode Perencanaan dan Perancangan

Aspek krusial dalam perencanaan ini adalah pada pemunculan citra budaya Jawa dalam bangunan tanpa mengurangi fungsi dari gedung Konvensi dan Ekshibisi itu sendiri. Aspek konsep perencanaan dan perancangan ini saling berkaitan satu sama lain seperti yang telah dijabarkan dalam bagan diatas. Citra budaya Jawa akan dimunculkan melalui tampilan dan atmosfer bangunan yang merupakan penerapan dalam perancangan dari data-data yang telah didapatkan. 


\section{HASIL DAN PEMBAHASAN}

\subsection{Tampilan Citra Budaya Jawa di Surakarta}

Dalam buku The Tourist Gaze (2001) sebuah tempat dipilih untuk ditonton karena adanya antisipasi, terutama melalui lamunan, fantasi, kesenangan yang mendalam yang melibatkan indra yang berbeda dari kebiasaan yang biasa mereka hadapi, Tourist gaze dibangun melalui tanda-tanda karena pariwisata merupakan pengumpulan tanda-tanda. Ketika wisatawan melihat dua orang berciuman di Paris apa yang mereka tangkap dalam tatapannya adalah romantisme romantis Paris, ketika melihat desa kecil di Inggris yang mereka lihat adalah 'real olde-Inggris' dan lain sebagainya. Begitu pula dengan Kota Solo, citra kota sebagai kota budaya sudah melekat lama di Kota Solo.

Apabila wisatawan biasa memilih tujuan wisata karena adanya antisipasi, tempat tujuan wisatawan MICE merupakan tempat tujuan yang telah ditentukan oleh instansi terkait dan membuat wisatawan MICE mau tidak mau mengunjungi tempat tersebut. Namun walaupun begitu seorang wisatawan (baik wisatawan biasa maupun wisatawan MICE) tetap akan melakukan research terlebih dahulu mengenai apa saja yang dapat dilakukan dan dapat dijumpai terkait dengan tujuan wisatanya nanti.

Jaman sekarang hampir semua orang tidak terlepas dari kegiatan yang berhubungan dengan gadget dan internet, mencari informasi sangatlah mudah hanya dengan berselancar di internet hanya dengan memasukkan keywordkeyword yang mewakili melalui search engine melalui gadget kita masing-masing dan akan muncul sangat banyak informasi yang bisa kita dapatkan. Ketika mengetikkan keyword "Wisata Solo" pada pencarian search engine sangat banyak muncul potensi-potensi menarik mulai dari tempat wisata yang bisa dikunjungi di Kota Solo hingga kuliner sedap yang dapat dicicipi di Kota Solo. Riset yang dilakukan wisatawan melalui internet ini nantinya akan dapat menumbuhkan bayangan dan harapan tentang apa yang nantinya akan wisatawan jumpai di Kota Solo saat nanti berkegiatan MICE di Kota Solo. Dan apabila wisatawan MICE ini dapat melihat dan merasakan langsung apa yang ia dapatkan dalam risetnya, wisatawan MICE akan merasa puas dan tidak menutup kemungkinan akan kembali lagi berkunjung ke Kota Solo sebagai wisatawan leisure.

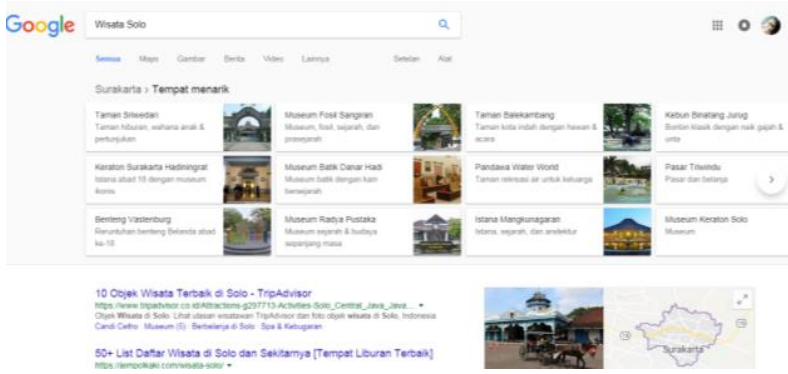

Gambar 1. riset "Wisata Solo" melalui internet

Berbicara tentang wisata budaya, dalam buku Consuming Tradition, Manufacturing Heritage (2001), satu hal yang sentral dalam wisata budaya adalah tentang authenticity. Wisatawan akan selalu mencari hal yang 'otentik' sesuai harapan mereka. Dalam kasus Kota Solo, authenticity ditunjukkan oleh institusi yang dianggap kredibel, dan seperti yang umum diketahui bahwa Kota Solo memiliki Keraton Kasunanan dan Pura Mangkunegaran yang merupakan dua warisan budaya yang telah lama berdiri dan juga menjadi tujuan wisata paling banyak dituju di Kota Solo. Keraton Kasunanan dan Puri Mangkunegaran ini merupakan wujud budaya yang dapat merepresentasikan budaya Kota Solo sehingga dapat diaplikasikan dalam bangunan gedung konvensi dan ekshibisi dan dapat menjawab bayangan dan harapan wisatawan akan riset mereka.

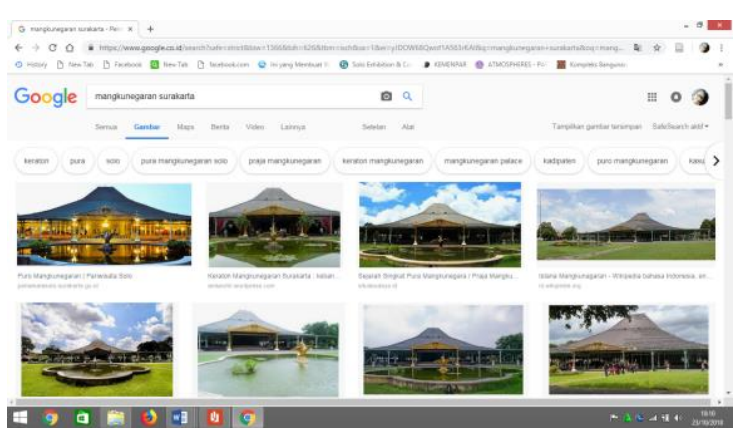

Gambar 2. riset "Mangkunegaran" melalui internet

Untuk Puri Mangkunegaran cukup melakukan riset melalui internet seperti pada Gambar 2 dapat diketahui bahwa bagian Pendhapa Mangkunegaran merupakan bagian yang paling merepresentasikan Puri Mangkunegaran. Namun selain riset melalui internet, dilakukan penyebaran kuisioner untuk mengetahui bagian 
dari Keraton Kasunanan Surakarta yang mana yang menurut wisatawan paling menarik dan merepresentasikan keraton Kasunanan Surakarta.

Partisipan kuisioner ini terdiri dari 50 orang dimana $80 \%$ berasal dari luar kota Solo dan $20 \%$ berasal dari kota Solo. Partisipan tersebut akan menuliskan 3 dari 9 bagian dari keraton yang menurut mereka paling menarik dan merepresentasikan keraton kasunanan Surakarta. Bagian tersebut adalah Gapura Gladag, Masjid Ageng, Sasana Sumewa, Sitihinggil Lor, Kori Brajanala, Kori Kamandungan Lor, Sangga Buwana, Museum Keraton, dan Bangsal Maligi.

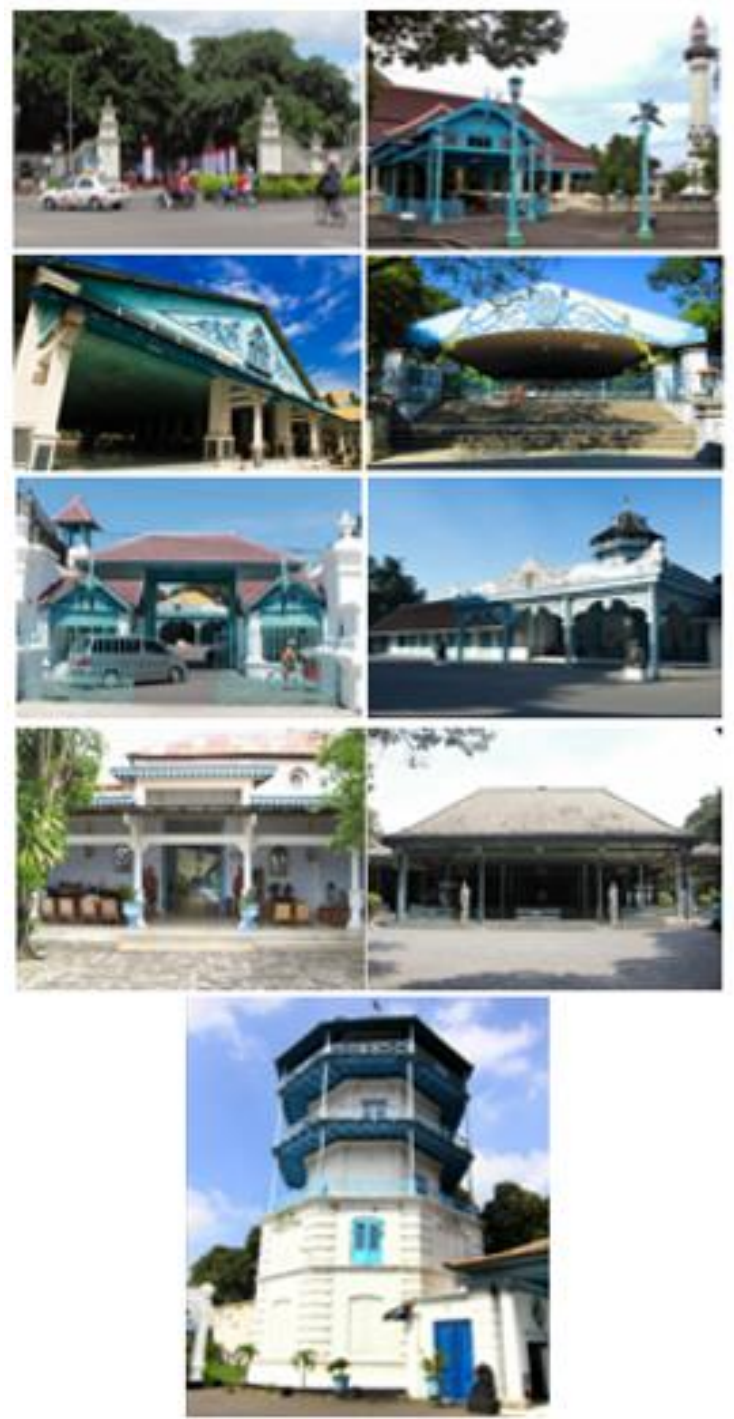

Gambar 3. 9 Bagian Keraton yang digunakan dalam Kuisioner
Adapun data jawaban responden kuisioner adalah sebagai berikut,

\begin{tabular}{|c|c|c|}
\hline $\begin{array}{c}\text { Bagian Keraton } \\
\text { Kasunanan Surakarta }\end{array}$ & $\mathbf{f}$ & $\%$ \\
\hline Gapura Gladag & 16 & $32 \%$ \\
\hline Masjid Ageng & 14 & $28 \%$ \\
\hline Sasana Sumewa & 30 & $60 \%$ \\
\hline Sitihinggil Lor & 5 & $10 \%$ \\
\hline Kori Brajanala & 5 & $10 \%$ \\
\hline Kori Kamandungan Lor & 45 & $90 \%$ \\
\hline Sangga Buwana & 26 & $52 \%$ \\
\hline Museum Keraton & 6 & $12 \%$ \\
\hline Bangsal Maligi. & 3 & $6 \%$ \\
\hline
\end{tabular}

Tabel 1. Data Kuisioner

Berdasar tabel 1 menunjukkan bahwa 3 bagian yang paling menarik dan merepresentasikan keraton kasunanan Surakarta adalah Kori Kamandungan Kor $(90 \%)$, Sasana Sumewa (60\%), dan Sangga Buwana (52\%).

\subsection{Atmosfer Budaya Jawa di Surakarta}

Setelah mendapatkan data melalui internet dan kuisioner, bagian dari Keraton Kasunanan dan Puri Mangkunegaran akan diaplikasikan dalam tampilan bangunan untuk memunculkan citra Budaya Jawa pada gedung konvensi dan ekshibisi yang merupakan tempat wisatawan MICE beraktivitas.

Seperti yang telah disebutkan dalam pendahuluan bahwa untuk memunculkan budaya Jawa pada bangunan, tidak cukup dilakukan hanya secara visual tampilan bangunan. Selain secara visual, atmosfer budaya Jawa juga harus dapat dimunculkan sehingga bangunan ini nantinya dapat merepresentasikan Kota Solo lebih dalam lagi.

Dalam setiap proses desain, Peter Zumthor selalu menggunakan pendekatan secara kasat mata, yakni 'pengalaman sensori' terhadap setiap objek arsitektural rancangannya. Pendekatan tersebut menjadi atmosfer desainnya yang kemudian dijabarkan dalam 9 aspek desain, berikut merupakan aspek desain yang akan diterapkan dalam perancangan bangunan Gedung Konvensi dan Ekshibisi: 


\section{a. Material compatibility}

Menurut Peter Zumthor, dalam mendesain kita harus memiliki kepekaan yang luar biasa terhadap material yang akan digunakan. Setiap material memiliki keunikan masing-masing. Material memiliki sifat yang 'berkelanjutan', fleksibel -tak ada batasan dalam mengelola dan menggunakannya. Jika dua material yang berbeda dikolaborasikan, pada titik tertentu mereka bertolak belakang, namun di satu titik mereka saling menunjang.

\section{$b$. The sound of a space}

Suatu bangunan memiliki 'nada' dan 'irama' dalam tiap ruangnya. Interior menjadi alat pembentuk suara, yang akan berkaitan dengan bentuk dan permukaan ruang (penggunaan material).

\section{c. Surrounding objects}

Aspek ini mengenai segala hal di sekeliling bangunan, berupa benda apapun, yang dapat membangkitkan suasana, imajinasi, keidahan, dan ketertarikan.

\section{$d$. The light on things}

Bangunan dianggap sebagai massa murni bayangan yang kemudian dilubangi dengan diberikan cahaya. Cahaya yang dimaksud adalah cahaya alami dan cahaya buatan. Dalam penggunaan material yang nantinya akan merefleksikan cahaya alami, ataupun dalam membuat bukaan dan menggunakan cahaya buatan, yang pertama diperhatikan adalah bagaimana jatuhnya cahaya, serta posisi dan bentuk bayangan nantinya efek tersendiri dan juga mempengaruhi kualitas spiritual bangunan.

Data-data mengenai aspek diatas dikumpulkan melalui cara wawancara dan juga survey lapangan guna mengetahui hal apa saja yang akan diterapkan ke bangunan untuk mendapatkan atmosfer budaya Jawa. Dari hasil metode pengumpulan data tersebut didapatkan hasil bahwa beberapa hal yang membuat atmosfer Budaya Jawa lebih terasa adalah penggunaan material bangunan yang identik dengan material rumah Jawa, penggunaan objek-objek interior maupun eksterior yang berhubungan dengan budaya Jawa dan masih banyak lagi hal yang dapat diterapkan di dalam bangunan.

\subsection{Penerapan Tampilan dan Atmosfer Budaya Jawa pada Gedung Konvensi dan Ekshibisi di Surakarta}

Rencana Pemerintah Kota Surakarta untuk membangun Gedung Konvensi dan Ekshibisi merupakan langkah pemerintah Kota Surakarta dalam mewujudkan Kota Surakarta sebagai salah satu destinasi MICE di Indonesia. Menerapkan citra Budaya Jawa pada Gedung Konvensi dan Ekshibisi ini merupakan upaya menunjukkan potensi yang dimiliki Kota Surakarta kepada wisatawan MICE yang berpotensi akan menjadi wisatawan leisure pada waktu yang akan datang. Aspek yang dimunculkan dalam tampilan bangunan merupakan aspek authenticity kota Surakarta yang didapatkan dari hasil riset internet kuisioner dan diperkuat dengan penerapan atmosfer desain Peter Zumthor yang didapatkan dari hasil wawancara juga survey lapangan.

Penerapan Budaya Jawa pada tampilan Gedung Konvensi dan Ekshibisi di Surakarta yang pertama adalah penerapan bentuk pendhapa yang merupakan lobi bangunan dan diletakkan dekat entrance tapak. Vegetasi di depan pendhapa ini tidak diberikan terlalu banyak sehingga ketika pengunjung memasuki entrance site bangunan akan langsung menyaksikan pendhapa tanpa terhalang vegetasi.

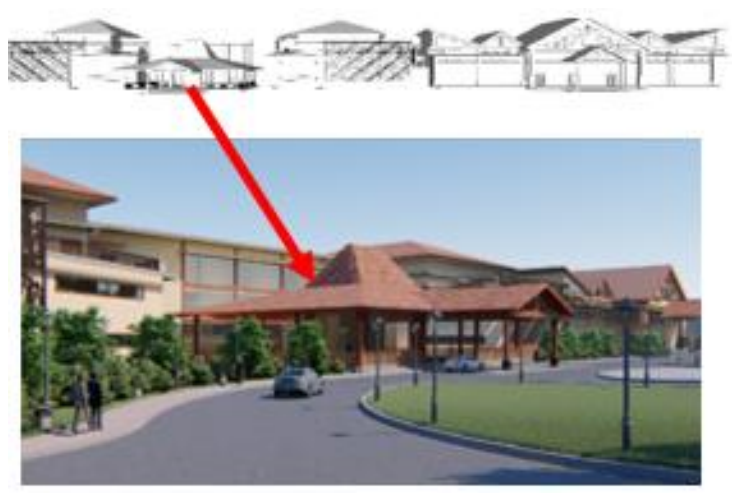

Gambar 4. Penerapan Pendhapa pada Gedung Konvensi dan Ekshibisi di Surakarta

Selain itu terdapat pengaplikasian teralis bangunan dengan bentuk motif batik parang sebagai secondary skin diletakkan di beberapa titik bangunan yaitu pada bagian selatan dan utara bangunan. 


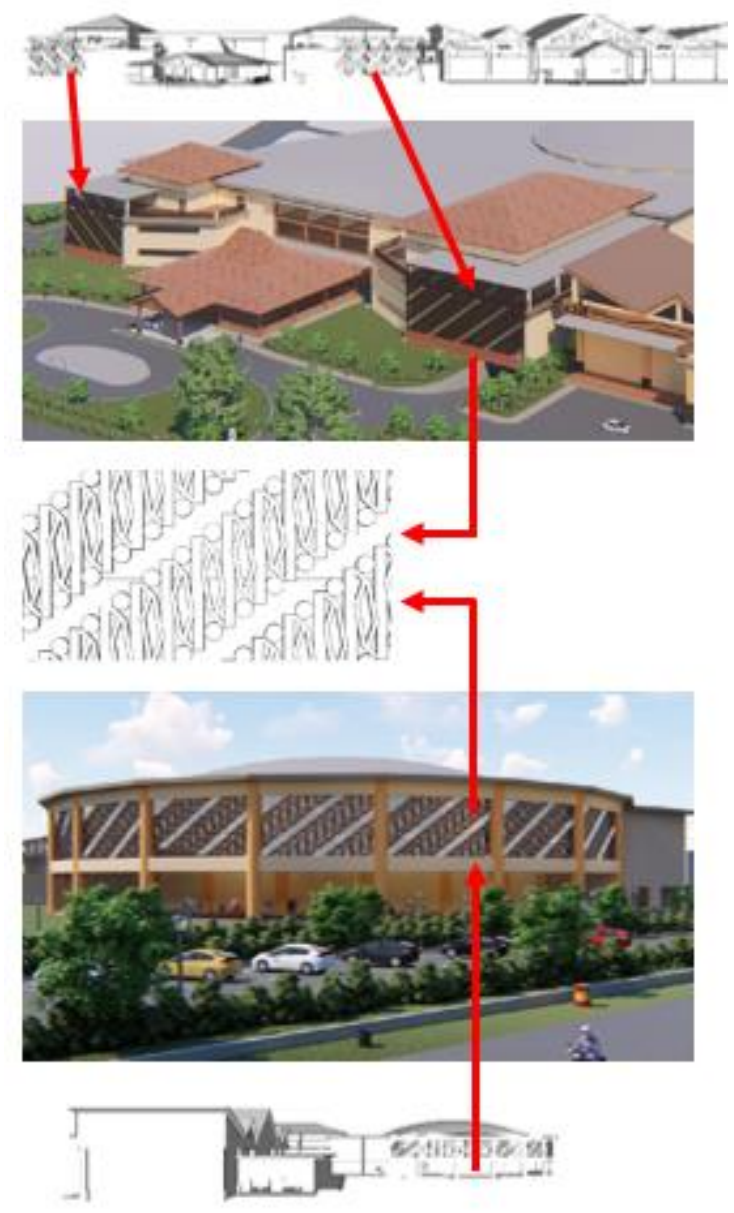

Gambar 5. Penerapan Teralis Motif Batik Parang pada Bangunan

Untuk penerapan pada fasad bangunan yang terakhir adalah penerapan bentuk Kori Kamandungan Lor dan Sasana Sumewa Keraton Kasunanan Surakarta diterapkan pada bagian Ekshibisi Indoor bangunan.

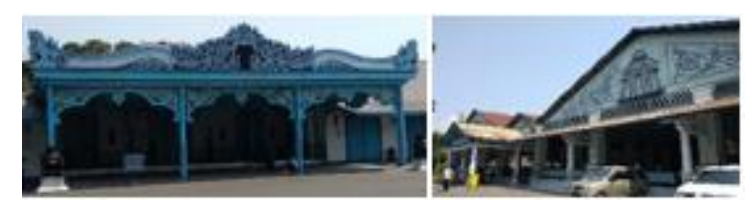

Gambar 6. Kori Kamandungan Lor dan Sasana Sumewa Keraton Kasunanan Surakarta

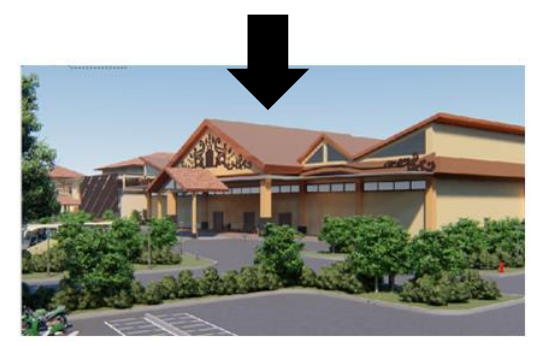

Gambar 7. Ekshibisi Indoor Gedung Konvensi dan Ekshibisi di Surakarta
Sedangkan untuk penerapan atmosfer budaya Jawa dalam bangunan yaitu dengan memunculkan aspek-aspek desain atmosfer Peter Zumthor dalam Gedung Konvensi dan Ekshibisi. Aspek material compatibility dengan pemilihan material bangunan yang identik dengan rumah Jawa seperti kayu, atap genting dan lain sebagainya. Material kaca diletakkan di belakang pendhapa sehingga ketika pengunjung masuk ke bagian penunjang tetap dapat merasakan atmosfer pendhapa melalui material kaca.

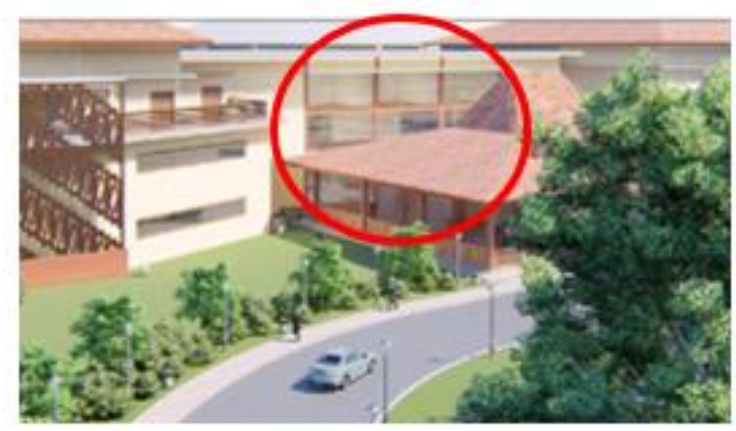

Gambar 8. Pemilihan Material Kaca Pada Bangunan

Material kayu juga diterapkan pada interior ballroom dengan susunan plafon seperti langitlangit pendhapa sehingga atmosfer budaya Jawa juga terasa di dalam ruang ballroom.

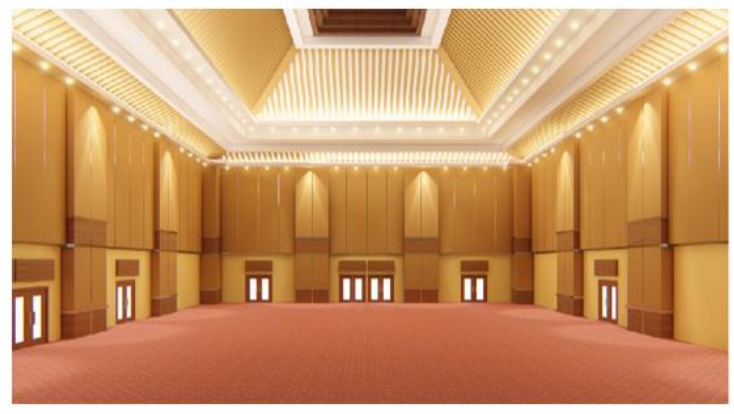

Gambar 9. Pemilihan Material Kayu pada Ballroom

Aspek Surrounding Objects dimunculkan melalui pemilihan benda-benda pada bangunan, seperti penggunaan instalasi pewayangan, gamelan, dan lampu gantung pada interior lobi. Pada bagian interior lobi ini juga dimunculkan aspek The Light on Things dengan membuat pencahayaan buatan yang menyorot pewayangan dan tumpang sari sehingga lebih menonjolkan budaya Jawa pada interior bangunan. 


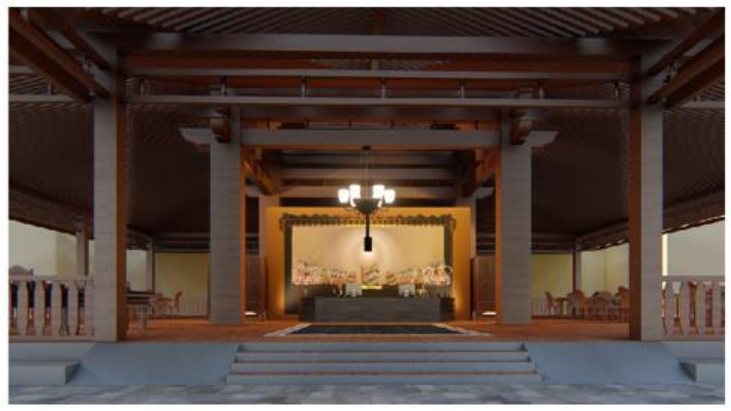

Gambar 10. Interior Lobi dengan Pemilihan Objek dan Pencahayaan Buatan yang Menonjolkan Budaya Jawa

Penggunaan teralis dengan bentuk motif batik parang juga akan memberikan efek pencahayaan alami ketika terdapat sinar matahari dari luar dan jatuh ke area prefunction bangunan.

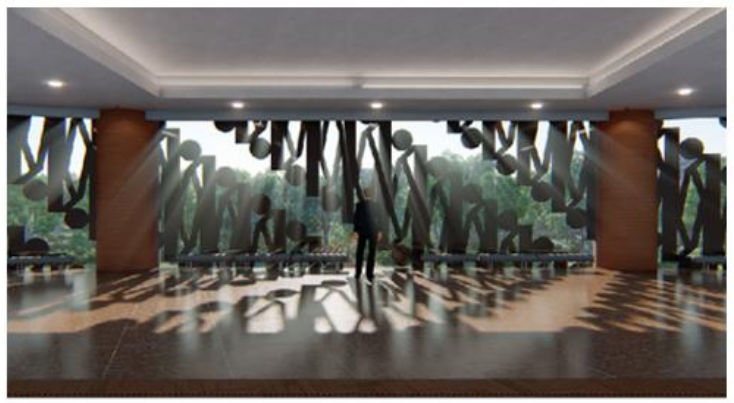

Gambar 11. Pencahayaan Alami pada Prefunction Area

\section{KESIMPULAN}

Seorang wisatawan akan melakukan riset terlebih dahulu mengenai apa saja yang dapat dilakukan dan dapat dijumpai terkait dengan tujuan wisatanya nanti. Hasil riset tersebut nantinya akan memunculkan antisipasi yang tentunya ingin didapatkan saat wisatawan berada di tujuan wisatanya. Kota Surakarta yang memiliki citra Kota Budaya memiliki banyak sekali potensi wisata di dalamnya, dan kita dapat mengetahui bayangan dan harapan seperti apa yang ingin wisatawan lihat di Kota Surakarta melalui riset internet dan kuisioner.

Rencana Pemerintah Kota Surakarta untuk membangun Gedung Konvensi dan Ekshibisi merupakan langkah pemerintah Kota Surakarta dalam mewujudkan Kota Surakarta sebagai salah satu destinasi MICE di Indonesia. Akan ada multiplier effects luar biasa dari pembangunan convention hall mengingat Kota
Surakarta yang tidak memiliki Sumber Daya Alam maka dari itu diperlukan adanya beberapa bangunan untuk menunjang aktivitas dan dinamika kota Solo sehingga kota MICE bisa terwujud.

Wisatawan MICE berpotensi menjadi wisatawan leisure sehingga sudah sepatutnya menunjukkan potensi-potensi yang dimiliki Kota Surakarta kepada wisatawan MICE melalui bangunan yang sedang digunakan dalam berkegiatan MICE di Kota Surakarta sehingga wisatawan mendapat jawaban akan bayangan dan harapan mereka dan diharapkan membuat para wisatawan akan berkunjung kembali ke Kota Surakarta di lain waktu sebagai wisatawan leisure.

Penerapan potensi-potensi yang dimiliki Kota Surakarta khususnya citra Budaya Jawa dalam bangunan diterapkan tidak hanya dari visual atau tampilan bangunan saja tetapi juga melalui atmosfer bangunan. Aspek yang dimunculkan dalam tampilan bangunan merupakan aspek authenticity kota Surakarta yang didapatkan dari hasil riset internet kuisioner dan diperkuat dengan penerapan atmosfer desain Peter Zumthor yang didapatkan dari hasil wawancara juga survey lapangan.

Penelitian ini sebagai riset awal yang diharapkan bisa menjadi dasar pada penelitian tentang perubahan wisatawan MICE menjadi wisatawan leisure.

\section{REFERENSI}

Alsayyad, Nezar. 2001. Consuming Tradition, Manufacturing Heritage: Global Norms and Urban Forms in the Age of Tourism. New York: Routledge.

Bioza, Betyona. 2017. Solo Craft Gallery Expo dengan Pendekatan Arsitektur Jawa Kontemporer. Hlm 270.

http://dx.doi.org/10.20961/arst.v15i1.12 182

Böhme, Gernot. 2005. Atmosphere as The Subject Matter of Architecture. Dalam Herzog and De Meuron: Natural History. Switzerland. Hlm 398-406. 
Kartikasunu, Danu. 2014. Solo MICE Hall dengan Penerapan Analogi Pendhapa. Tersedia dari:

https://jurnal.uns.ac.id/Arsitektura/articl e/view/15764/12696 [Diakses pada: 18 September 2018].

Urry, John. 2001. The Tourist Gaze. New Delhi: SAGE Publication Ltd.

Zumthor, Peter. 2006. Atmospheres. Switzerland: Birkhauser 